\title{
Behavioral economics approaches to public policy
}

\author{
Adrian Solek \\ Cracow University of Economics \\ Poland \\ e-mail:adrian.solek@uek.krakow.pl
}

\begin{abstract}
The relatively new school of thought - behavioral economics is complementary to the neoclassical model of decision making, as it accounts for psychological factors underlying people's choices, which are omitted by standard models. Several cognitive tendencies have been identified. These findings may be used by policy makers as tools of furthering desirable behavior of individuals. Such regulation may take the form of either soft or more heavy-handed paternalism. However its implementation raises some criticisms, ranging from practical issues to more fundamental questions of respecting freedom of choice. The presented paper compares the ways in which decisions and choices are addressed in neoclassical and behavioral economics and implications of their assumptions and findings for policy measures that may be taken by the government. Controversies elicited by paternalistic approaches have also been elaborated.
\end{abstract}

DOI:

Keywords: behavioral economics, behavioral biases, regulation, paternalism

JEL classification: D03, H10, L51

\section{INTRODUCTION}

In recent economic literature an ever-growing attention is put on determinants of human behavior that used to be beyond the interest of traditional economic research. An increasing body of psychological research shows that decision makers are susceptible to cognitive biases and in consequence their choices are frequently far from predictions of standard neoclassical economic models. These findings are the core of behavioral economics, which studies actual decision made by individuals rather than prescribing the course of action to be followed. After a number of deviations from the standard model have been identified (Kahneman 2003), an important question arises whether and how the results of the research can be used to ameliorate decisions and make them consistent with people's interests. This matter is of great value, as traditional incentives in form of monetary signals are sometimes insufficient to induce the desired behavior.

A growing number of studies have been devoted to practical methods of application of the findings of behavioral economics in particular areas, such as health behavior, insurance, savings, environmental policy (Congdon, Kling, Mullainathan 2011; Foote, Goette, Meier 2009; Gowdy 2007). However, relatively few deal with more fundamental problems of the government's involvement in correcting people's mistakes, e.g. how behavioral economics relates to the notion of individualism, freedom and responsibility of decision 
makers (Camerer et al. 2003; Saint-Paul 2011; Wright, Ginsburg 2012). The aim of this paper is to present major behavioral biases affecting individuals' choices, possible methods of making use of them in public policy so as to overcome cognitive problems of the persons involved, and to draw attention to controversies connected with such regulatory approach, regardless of how little intrusive it is.

\section{DECISION MAKING IN BEHAVIORAL AND NEOCLASSICAL ECONOMICS APPROACH}

Neoclassical microeconomics builds on the principle of ethical and methodological individualism (Acocella 2005). According to these perspectives individuals know best their own preferences and the welfare of a society is reduced to satisfaction derived from a given state by individuals. Preferences are treated as given and the process of their creation is outside the scope of traditional economics. They cannot be assessed and valued as right or wrong, and their analysis is limited to comparing the actual choices made by decision makers. In revealed preference theory, a choice is an expression of preferences, i.e. if a consumer purchased bundle $a$ instead of $b$ while both were available, it implies that he prefers $a$ over $b$ or the former bundle generates a higher level of utility.

Moreover, neoclassical economics assumes full rationality of decision makers. The meaning of this concept is somewhat narrower that a layman would imagine. An individual is rational if his preferences are complete, transitive and independent of irrelevant choice options. It must be stressed that rationality defined as above must not be identified with pursuing happiness, satisfying one's own interest or any other goal - all it means is making choices in accordance with the three axioms (Hausman, McPherson 2008). The subjectivity of preferences excludes making judgments upon them, since every individual may order choice options as he/she wishes.

For this reason a prescriptive implication of the neoclassical approach is free market, by principle undisturbed by any intervention of public authorities. The government should act primarily as a "night watchman" with its role limited to providing a legal framework for voluntary transactions between agents. On the ground of neoclassical microeconomics the only rationale for the government intrusion is market failures, or instances when social welfare, being the sum of individual utilities, is not maximized, due to imperfect competition, externalities, asymmetric information or problems with the provision of public goods.

As regards influencing behaviors of agents, the standard economic model recommends providing full information to decision makers to avoid moral hazard or adverse selection, creating markets and defining property rights in cases where markets are nonexistent, and using economic incentives, e.g. taxes and subsidies, in order to bring market prices into line with full social costs and benefits of the activities in question. However, empirical studies show that such measure may be insufficient to reach desired goals or even may have adverse effects (e.g. Gneezy, Rustichini, 2000). A plausible explanation is that neoclassical economics takes the assumption of a too simplified model of decision agent - a homo oeconomicus, whose only concern is to weigh benefits of possible courses of action versus their costs and choose the optimal option accordingly. An alternative school of behavioral sciences, developing fast since 1970s, combines economics with psychology to give insights into more sophisticated aspects of human nature. Unlike standard economics, which is concerned with developing theoretical models based on a small number of assumptions, the behavioral approach draws heavily on empirical observations which demonstrate actual choices made by people who frequently act as if they were apparently irrational or didn't follow their own narrowly defined interests. The observations either come from the "natural environment" of decision makers (such as stock exchange) or are results of experiments in which different settings and treatments are used to elicit the subjects' reaction to in- 
centives mimicking real-life situations (see e.g. Smith 2009). A number of regular patterns have been identified in this kind of apparently erratic behavior; they can be divided into three major categories: imperfect optimization, bounded self-control and nonstandard preferences (Congdon, Kling, Mullainathan, 2011).

The first group of deviations from the standard economic model consists of cases in which a decision maker does not take all relevant information into account or the information is inconsistent. The suboptimal choice may be a result of limited attention, limited computational ability or biased reasoning. Limited attention refers to situations when the most salient elements of the environment have dominant influence of the decision, or local construals, when the individual selectively directs his or her attention to a particular element, thus failing to notice other - perhaps equally important - factors that could affect the choice. Limited computational abilities may lead to decisional conflicts, where the decision maker is overloaded with too many choice options, which makes it hard or impossible to make full benefit-cost analysis of each of them prior to selecting the most optimal alternative. The same constraints also imply inconsistent subjective valuation of goods (e.g. willingness to pay is different from willingness to accept, depending on whether the good belongs to the individual or not) or malleable. Another effect, called schmeduling, consists in problems with understanding complex price schedules (such as confusing average and marginal prices, since the former is easier to understand and calculate). One more implication of inadequate computational skills is mental accounting - the tendency to treat income from various sources differently, rather than consider the money as fungible and focus on maximizing the overall sum of one's capital. Finally, biased reasoning refers to problems with making correct judgments whenever risk is involved. A number of rules of thumb, called heuristics, are used as shortcuts when probabilities need to be computed prior to making a decision. The assessed probability of an event increases, if the event is easy to recall or imagine (availability heuristics). The relative frequency of alternative events is often ignored (representativeness heuristics). Low probabilities are overestimated while frequent events are thought to be less probable than they actually are. In addition to that, several motivational biases have been discovered - decision makers tend to be overly optimistic and confident about their own chances of success and tend to consider their own self-interested judgments as fair.

The second category of deviations from the standard economic model deals with human problems with implementing their choices, or put differently, keeping consistency between their intentions and actions. The bounded self-control translates into overestimating current benefits and underestimating future costs of today's decisions. In terms of intertemporal choice, individuals do not weight current event versus future event using constant discount rate, distinctive for exponential discounting, but instead use decreasing rate, typical for hyperbolic discounting. As a result problems with procrastination (failing to take actions previously intended) or temptation (taking actions one previously wanted to avoid) may arise. One can interpret these situation as if the person were composed of different selves: one of the them makes the decision which should be implemented by some future incarnation, however the obligations put by the current self on the future one are not obeyed. An interesting finding is the fact that the gap between intention and action may grow or diminish in reaction to very slight variations of the choice context (Madrian, Shia 2001). These channel factors may significantly modify the decision, for instance providing a map to the nearest clinic will considerably increase the number of people who get vaccination as compared to the group without such information. The degree of exerting self-control depends, among others, on the current state of the decision makers and their emotions - stress, information overload or fear may trigger impatience. People also display projection bias, which means they tend to project their current preferences onto future selves. To end with, a representative example of problems with self-control is addiction as inability to stick to one's previous consumption preferences. 
As regards the third group of deviations, nonstandard preferences take into account factors that are usually ignored by the standard economic model. As it turns out, the choice depends heavily on the context in which it is presented. People account for their expectations as well as the present situation when making a decision. The reference-dependent preferences are manifest in case of the endowment effect, where individuals assign different values to the same goods depending they have it or not and in consequence their willingness to pay is lower than willingness to accept. This finding is connected with loss aversion - the fact that people perceive losses more intensely than gains, which results in a tendency to avoid changes in the present situation in order not to incur a possible loss (status quo bias). A different type of non-standard preferences includes having interest in the outcomes of other people, rather than focusing on one's own welfare. Thus individuals regularly exhibit altruism rather than pursuing their own interest, prefer fair distribution to inequitable and obey other social norms that are dropped out in neoclassical models. Other-regarding preferences are also displayed when a person's utility depends not only on the absolute value of their assets, but on their relative position in a comparison with others.

The behavioral tendencies describe above are summarized in Figure 1 below.

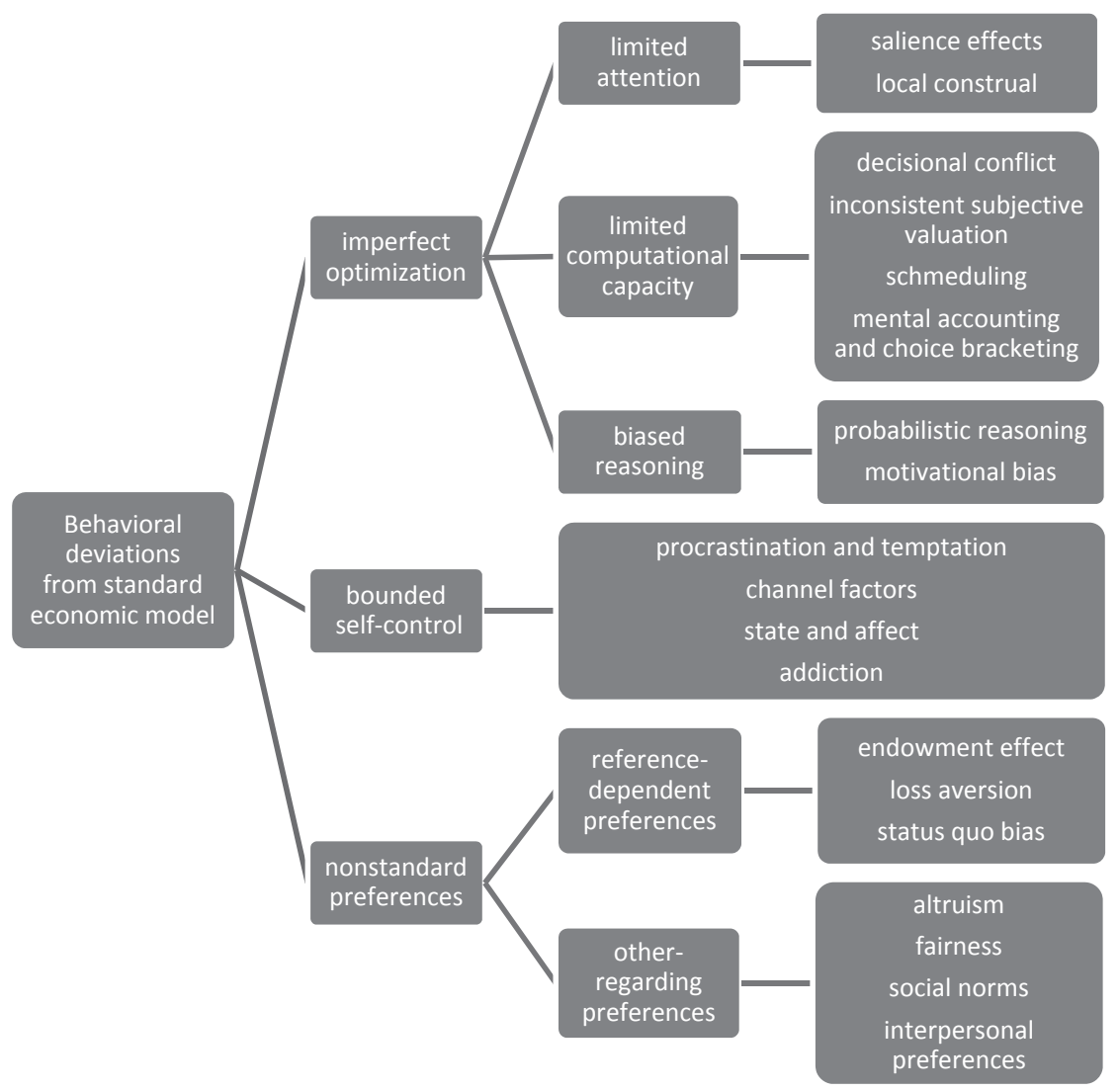

Figure 1. Behavioral deviations from the standard economic model Source: own work based on: Congdon, Kling, Mullainathan (2011). 


\section{TYPES OF PATERNALISM}

In the opinion of supporters of behavioral economics, in cases where many people display cognitive biases or a lack of self-control, the role of the government should not be limited to minimal state. Confining to assert that every choice an individual makes is per se optimal and self-legitimizing is a tautology, but it is also in sharp contrast to situations where the decision obviously hurts the person who made it: "Economists will and should be ignored if we continue to insist that it is axiomatic that constantly trading stock or accumulating consumer debt or becoming a heroin addict must be optimal for the people doing these things merely because they have chosen to do it" (O’Donohue and Rabin, 2003).

Since individuals cannot free themselves from decision errors, debias their cognitive tendencies or ensure more self-control, it would be somewhat natural to think of the government as the agent who should give them a helping hand. In consequence the behavioral approach to economic choices implies a much greater scope for public policy than neoclassical economics.

On the one hand, the above behavioral biases are a rationale for public policy aiming at ameliorating people's choices, on the other hand - the government may well make use of psychological mechanisms to fine-tune its regulations to achieve the desired goal. There are numerous areas in which such behaviorally supported intervention may prove particularly useful and successful. These include promoting healthy behavior (fighting obesity and addiction), increasing savings for the retirement, buying insurance policies, environmentally friendly behavior and so on, as well as fighting poverty and inequality and raising tax compliance (Congdon, Kling, Mullainathan 2011). As a matter of fact, the scope of using behavioral insights in public policy is virtually unlimited, due to their universality.

The regulation enhanced with contribution of behavioral sciences may take different forms, depending on the degree of intrusiveness of the government into individual choices. Among most popular proposals of methods of public engagement are: libertarian paternalism, optimal (asymmetric) paternalism, recovering preference and "do not harm" approach.

Libertarian paternalism (Sunstein, Thaler, 2008) consists in inducing behavior that is considered healthy, wealth-maximizing or otherwise desirable without restricting the number of options available to a decision maker. The options that make the individual better off are made more salient and, since people are susceptible to framing effects and availability heuristics, they would tend to chose the alternatives to which their attention has been drawn, with all other options still accessible. According to the proponents of this form of regulation, it should be acceptable to most keen libertarians because it does not involve coercion and leaves freedom of choice through the possibility to opt out of the suggested course of action. Besides, there are cases where some form of paternalism in necessary, because some default options must be presented to the decision maker. It is the role of the policy maker to design the choice architecture so it influences behavior in the desired way. For example promoting healthy lifestyle would suggest displaying products in a supermarket so that organic food is most visible, without forcing anyone to buy them or forbidding to purchase products high in fat and salt. A number of tools consistent with the concept of libertarian paternalism, or 'nudges', have been proposed (Thaler, Sunstein, 2003; Johnson et al. 2012). They include, among others, presenting the desired alternatives as defaults rather than opt-in options (e.g. in case of organ donation consent), an idea which draws on the status quo bias, or saving programs for smokers who want to quit the habit, in which the deposit is paid back after a specified period only if the person passes the medical test confirming she has not smoked recently (otherwise the money is donated to a charity), which is meant to help people solve problems with a lack of self-control. Generally speaking, these solutions belong to one of two categories: they either structure the choice in a certain way or describe the options in a specific manner. Additionally, another category of tools aimed at the successful implementation of the decision may be distinguished (Table 1). 
Choice architecture tools

\begin{tabular}{|l|l|l|l|}
\hline \multicolumn{1}{|c|}{ Tool category } & \multicolumn{1}{c|}{ Problem } & \multicolumn{1}{c|}{ Choice architecture tools } & \multicolumn{1}{c|}{ Examples } \\
\hline \multirow{4}{*}{ setting up the task } & alternative overload & reduce number of alternatives & investments \\
\cline { 2 - 4 } & technology and decision aids & sorting on attributes \\
\cline { 2 - 4 } & decision inertia & use defaults & organ donations \\
\cline { 2 - 4 } & myopic procrastination & focus of satisficing & job search \\
\cline { 2 - 4 } & limited time windows & retirement planning \\
\cline { 2 - 4 } & long search process & decision staging & automobile customization \\
\hline describing the options & naïve allocation & partitioning of options & food menus \\
\cline { 2 - 4 } & attribute overload & $\begin{array}{l}\text { attribute parsimony and } \\
\text { labeling }\end{array}$ & $\begin{array}{l}\text { good/bad labels for numeric } \\
\text { information }\end{array}$ \\
\cline { 2 - 4 } & non-linear attributes & $\begin{array}{l}\text { translate and rescale for better } \\
\text { evaluability }\end{array}$ & credit card repayments \\
\hline \multirow{2}{*}{ implementation issues } & individual differences & customized information & energy conservation \\
\cline { 2 - 4 } & outcome valuation & focus on experience & cooling off periods \\
\hline
\end{tabular}

Source: adapted from: Johnson et al. (2012).

A slightly more intrusive form of regulating behavior is asymmetric or optimal paternalism (Camerer, 2003; O'Donoghue, Rabin, 2003), where the measures taken in order to put people's choices in line with their interests interfere only minimally with interests of those who behave rationally. In the opinion of its supporters, an asymmetrically paternalistic policy should be furthered if it generates higher gains for bounded rational individuals and firms than the sum of costs for rational decision makers and costs of implementation. An example is a "cooling off period" - the possibility to send back any item bought in an door-to-door sale, when the decision of purchase would not be made after a more thoughtful consideration. Obviously such a solution restricts the freedom of trade within the specified time after the purchase, by forcing the sellers to accept the goods returned by consumers, however many would advocate introducing such laws to compensate for the negative effects of impulse shopping. Another instance of optimal paternalism is a "sin tax", imposed upon goods whose consumption by some people is the result of bounded self-control, such as cigarettes. Putting a tax on these products hurts people who don't exhibit such behavioral biases and optimally choose the amount of cigarettes purchased, weighing the benefits of the decision against its current and future costs. On the other hand the tax is beneficial for people who would otherwise buy too many cigarettes due to insufficient self-control and later regret their own choice. Thus endorsing such regulation improves social welfare (considered as the sum of welfare of all individuals, including the "future incarnations" of boundedly rational consumers) and although is not a Pareto improvement, meets the Kaldor-Hicks criterion.

Another approach to public policy accounting for behavioral factors is a compromise between the revealed preference theory as a core element of neoclassical microeconomic theory and findings of behavioral sciences. By default, one assumes that the choices made are manifestations of preferences, unless there is evidence for the contrary, e.g. when the choices are not consistent. In the latter case, additional results of economic, psychological or neuroscience research are taken into account to determine what maximizes welfare of individuals and implement a course of action accordingly (Bernheim, Rangel, 2009). For example, smoking cigarettes may be a result of one's optimal decision to maximize own welfare, but as medical and psychological research suggests, it reduces consumers' welfare, though they may have problems quitting the 
habit previously taken up. Therefore policy makers may decide to introduce laws that would decrease cigarette consumption to increase the social welfare. Such an approach widens the standard welfare economics model to make them include behavioral models of behavior.

It is possible to think of defending even more heavy-handed paternalistic policies on the grounds of serving the long-term interests of people involved. A case in point is occupational safety law, which prohibits workers to give up some extent of safe work conditions in return for an increase in salary. However it should be obvious that the more interfering the regulation, the more problematic it may be to prove that the line delimiting the acceptable extent of government's intrusion has not been pushed too far.

As the arguments for any weak form of paternalism might be rejected by proponents of libertarian approach, let alone more oppressive and choice-restricting regulations, another idea has been developed that aims at advancing individual freedom of choice instead of dictating people choices (Mitchell, 2005). It rejects the libertarian paternalism on the grounds that for people with unstable preferences even the possibility of opting out from the default option is meaningless due to limited capability to decide what is best, thus the real choice for them is restricted to the alternative suggested by the policy maker. Instead, the "do no harm" approach calls for making people less sensitive to choice architecture manipulations. Thus, errors resulting from context-dependence ought to be corrected by encouraging people to reframe the problem of choice, e.g. by asking them to imagine the consequences of failure of the chosen alternative and the implications of selecting a rejected option. A more deliberate consideration of the decision problem, including reflection upon counter-arguments and opposing viewpoints, might also be persuaded, with the aim to replace quick and emotion-induced decisions. Issues consisting in limited selfcontrol, such as procrastination and engaging in addictive activities, can be overcome or at least alleviated if the individual considers consequences of their actions or possible future scenarios. One may make use of empirical findings, e.g. the rather surprising fact that self-control seems to decrease in the course of the day, and encourage people to take important decisions with long time horizon in the morning, before a number of temptations sets in (Kouchaki, Smith 2014). This debiasing approach is narrowed to making people realize the shortcomings of their cognitive abilities instead of "tricking" them into selecting choices desired by the policy maker. Hence its ultimate goal is maximizing liberty rather than maximizing welfare as defined by the government.

\section{USING BEHAVIORAL TOOLS IN PUBLIC POLICY}

Before applying behavioral techniques policy makers should find answers to a number of key questions regarding:

- the problem they need to tackle;

- identification of target groups that the policy will address and differences between them in terms of attitudes and motivations, which should help create a nuanced plan of actions;

- recognition of practical and structural barriers faced by individuals, imposed upon them by context in which they act;

- availability of effective choices for different groups in the society;

- the scope for improvement of current policies;

- possible intended and unintended consequences of the new procedures;

- methods of engaging the society into the process of solving the issue in question, as well as ways of facilitating public debate and gaining approval and, where necessary, legitimacy and the most suitable format of deliberation (Dolan et al., 2010). 
Once the answers to the above questions have been found, a cafeteria of solutions based on insights from behavioral economics may be applied. These include:

- an appropriate framing of the choice context, with suggested alternatives as default or most salient options,

- providing comprehensible information and allowing a longer period to ponder upon the issue before the decision is made,

- introducing commitment devices, e.g. cooling off periods or financial products that would prevent withdrawal of money before deadline or in case of succumbing to a bad habit,

- attempting to change social norms, drawing on people's impressions of themselves as "good citizens",

- priming, or using certain cues (exposition to specific sights, words, sensations), such as making people realize of the problem to be solved.

Possible responses to behavioral tendencies have been describe more extensively in table 2 .

Table 2

Implications for policy based on behavioral approach

\begin{tabular}{|c|c|c|}
\hline Neoclassical economics approach & Behavioral economics approach & Implication for policy making \\
\hline $\begin{array}{l}\text { preferences are exogenous; influence } \\
\text { of other people on shaping preferences } \\
\text { is ignored; institutions and evolution } \\
\text { of economic systems are disregarded }\end{array}$ & $\begin{array}{l}\text { individuals learn by observing } \\
\text { other people, especially in ambiguous } \\
\text { situations, in crises and if others are } \\
\text { experts; individuals favor in-group } \\
\text { members and are open to influence } \\
\text { from people they like }\end{array}$ & $\begin{array}{l}\text { change social norms to make the effect } \\
\text { of policy last longer; influence people } \\
\text { who enjoy authority in the community }\end{array}$ \\
\hline $\begin{array}{l}\text { only consequences of decisions are } \\
\text { analyzed; choices made out of habit } \\
\text { outside of scope of the theory; deci- } \\
\text { sion makers maximize their utility }\end{array}$ & $\begin{array}{l}\text { frequency of past behaviors affects } \\
\text { current actions; habits are difficult to } \\
\text { change the more often they are repeat- } \\
\text { ed, the stronger they are connected to } \\
\text { rewards and the sooner the rewards } \\
\text { come; conscious deliberation prior to } \\
\text { decision happens more often when the } \\
\text { decision is complex, its consequences } \\
\text { are important, there is enough time } \\
\text { and knowledge to consider them }\end{array}$ & $\begin{array}{l}\text { consider the role of habits and meth- } \\
\text { ods of "unfreezing" them; find incen- } \\
\text { tives for their change and immediate } \\
\text { feedback to reinforce new behavior }\end{array}$ \\
\hline $\begin{array}{l}\text { financial incentives motivate people to } \\
\text { change behavior; altruistic motives are } \\
\text { excluded from analysis }\end{array}$ & $\begin{array}{l}\text { financial incentives may demotivate } \\
\text { people and crowd out intrinsic motiva- } \\
\text { tion; people care about fairness of } \\
\text { their actions }\end{array}$ & $\begin{array}{l}\text { if the behavior to be changed is } \\
\text { considered shameful, fines may be } \\
\text { counter-productive, and similarly } \\
\text { rewards for honorable acts; the policy } \\
\text { and the institution that implements it } \\
\text { must be regarded as fair }\end{array}$ \\
\hline $\begin{array}{l}\text { self-expectations about one's own } \\
\text { behavior, attitudes and values are } \\
\text { ignored, commitments and promises } \\
\text { are disregarded unless backed by } \\
\text { sanctions }\end{array}$ & $\begin{array}{l}\text { individuals try to reduce cognitive } \\
\text { dissonance - a gap between actions } \\
\text { and attitudes or values; a prospect of } \\
\text { feeling shame affects behavior }\end{array}$ & $\begin{array}{l}\text { use voluntary commitments, espe- } \\
\text { cially public, written, made by groups } \\
\text { and using existing points of contact; } \\
\text { commitments should be realistic to } \\
\text { fulfill, starting from easiest to more } \\
\text { demanding; people must be actively } \\
\text { involved }\end{array}$ \\
\hline
\end{tabular}




\begin{tabular}{|l|l|l|}
\hline $\begin{array}{l}\text { willingness to pay is equal to willing- } \\
\text { ness to accept; people are neutral to } \\
\text { losses and gains }\end{array}$ & $\begin{array}{l}\text { individuals are loss-averse; they put } \\
\text { more effort into preventing a loss than } \\
\text { winning a gain (value losses more } \\
\text { than gains); they assess losses and } \\
\text { gains relative to status quo }\end{array}$ & $\begin{array}{l}\text { use willingness to accept when people } \\
\text { reasonably have a right to something } \\
\text { that might be taken away from them; } \\
\text { use willingness to pay when they have } \\
\text { a right to status quo and an improve- } \\
\text { ment is proposed; fines are stronger } \\
\text { disincentives than similar-sized } \\
\text { rewards are incentives; taxes taken } \\
\text { at source are easier to introduce than } \\
\text { taxes paid actively }\end{array}$ \\
\hline $\begin{array}{l}\text { individuals are rational and act logi- } \\
\text { cally; they are able to compare avail- } \\
\text { able options and select the optimal } \\
\text { one; they use exponential discounting } \\
\text { when solving intertemporal choice } \\
\text { problems }\end{array}$ & $\begin{array}{l}\text { people use rules of thumb (heuristics) } \\
\text { when making complex decisions; they } \\
\text { overestimate the likelihood of salient } \\
\text { events and those with low probabili- } \\
\text { ties, and underestimate probabilities of } \\
\text { frequent events; they use hyperbolic } \\
\text { discounting, are susceptible to framing } \\
\text { effects and defaults; they display over- } \\
\text { confidence; they undervalue goods } \\
\text { given for free }\end{array}$ & $\begin{array}{l}\text { vividly described; immediate losses } \\
\text { are stronger incentives than long-term } \\
\text { rewards; commitment technologies } \\
\text { should be used to prevent procrastina- } \\
\text { tion and temptation }\end{array}$ \\
$\begin{array}{l}\text { increasing the amount of information } \\
\text { or the number of alternatives does not } \\
\text { make a person worse off (additional } \\
\text { information or option may be used } \\
\text { for the benefit of the individual or } \\
\text { ignored) }\end{array}$ & $\begin{array}{l}\text { more choice options and information } \\
\text { is overwhelming and impedes the } \\
\text { efficacy of decision making; telling } \\
\text { people what to do is demotivating }\end{array}$ & $\begin{array}{l}\text { choice option should be clustered to } \\
\text { avoid information overload; graphical } \\
\text { information should be used to enhance } \\
\text { comprehension; people should be } \\
\text { encouraged to participate in policy } \\
\text { design; governments should build on } \\
\text { existing groups and initiatives }\end{array}$ \\
\hline
\end{tabular}

Source: own work based on: Dawnay, Shah (2005).

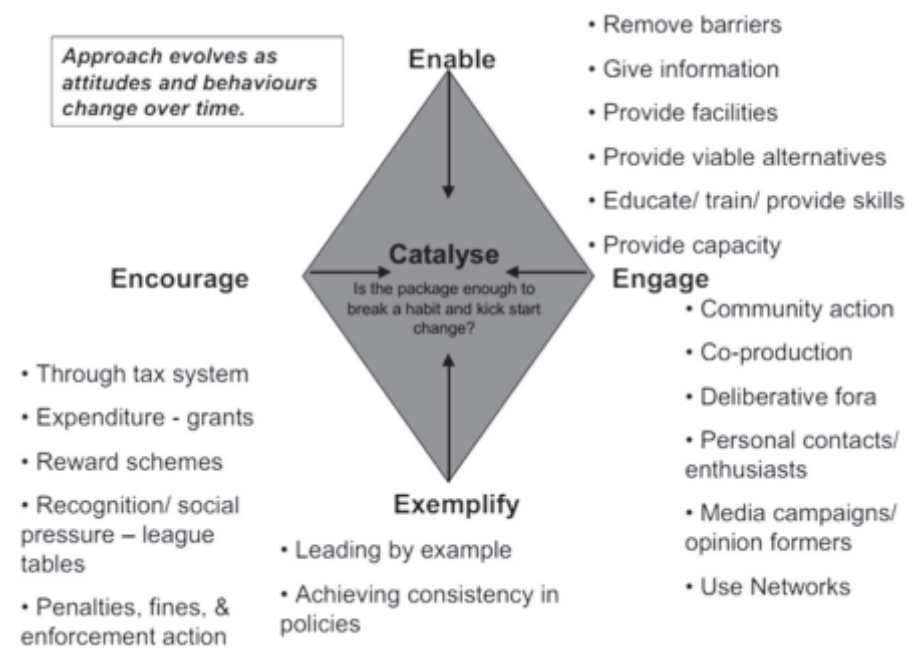

Figure 2. A comprehensive approach to behavioral change through policy making Source: Sustainable Development Unit in Defra (2005). 
Of particular importance is the fact that in order to win trust of the involved individuals the public authorities need to serve as an example. Failure of government bodies to exhibit the behavior they try to encourage in others can be perceived as a symptom of hypocrisy and inconsistency, and in consequence such policy will be counterproductive, as reciprocity and fairness are among crucial factors determining people's behavior. Needless to say, a final evaluation of outcomes is necessary as well as correction of the measures used if they turn out to produce effects below expectations.

Obviously the suggested tools may and should be used together to enhance their effect on actions of individuals, as well as a combination of incentives drawing on behavioral findings and standard economics (e.g. taxes, fines, financial rewards etc.). The comprehensive framework for using the measures in public policy is shown in Figure 2.

\section{CRITIQUE OF PATERNALISTIC APPROACHES TO PUBLIC POLICY}

The list of objections to paternalistic policies is long and encompasses criticisms ranging from fundamental, philosophical one to more practical, down-to-earth issues.

Paternalism can be regarded as a case of an ethical stance called consequentialism, or its specific version, utilitarism. For consequentialists it is the final outcome that matters, not the methods of achieving the goal - "the ends justify the means". Utalitarians' general target is maximizing pleasure and minimizing pain, and if we relate the goal to public policy, the objective of the society should be defined as pursuing the highest possible level of social welfare. Consistent with this goal are procedures that involve restrictions of individual freedom as the price paid for an increase in happiness. Obviously this position raises controversies and is not widely accepted.

The libertarian approach praises the freedom of choice as a superior value, and at the same time it links liberty to responsibility. People should be free to choose whatever they want and ought to bear the risk and consequences of making a foolish decision, libertarians claim. On the other hand paternalistic policies try to limit the freedom of choice and simultaneously pass the responsibility for unwanted behavior to someone else - either the government or other, more "rational" individuals, less prone to behavioral errors.

It is important to recall the meaning of rationality here, as it is understood in mainstream economics. This concept has nothing to do with the judgment of the choices made - all it is about is the consistency of the choices, no matter whether they are considered sensible, desirable or silly. By definition, in revealed preference theory an option is said to maximize the individual's utility if it is chosen instead of any other available alternative. Choice is thus a symptom of preference. In consequence it is impossible to maintain that a person made a decision that would not maximize his/her utility. An important consequence is that one cannot identify utility with happiness - all it means is only a representation of a person's ranking of possible options.

In order to overcome problems with interpersonal comparison of utility, paternalism needs to use some cardinal measure of welfare in place of utility, having the ordinal character. For this reason "happiness" often takes the role of a criterion of evaluating outcomes. However, it cannot be observed directly, hence the need to apply indirect methods of its calculation, e.g. surveys (Saint-Paul, 2012). But whatever measure of welfare is decided upon by the policy maker, it will probably be unacceptable to some people, so its legitimacy may be disputed.

Advocates of mainstream economics argue that economics should stick to the revealed preference, since any departure from choice is beyond the scope of this discipline - "welfare theory is not a blueprint for a social movement" (Gul, Pesendorfer, 2005). An argument for this standpoint indicates that it is difficult 
to distinguish a person who carefully weighs all pros and cons (also in the intertemporal aspect) and deliberately chooses to engage in "harmful" behavior, such as smoking or gambling, from a person who acts in the same way, because is insufficiently determined or unable to keep her own resolution to abstain from these addictive actions. Thus restricting this type of activities will benefits persons of the second type who need some commitment tools, at the cost imposed upon rational individuals of the first type whose welfare will be reduced.

Since problems with self-control allow for the interpretation that in behavioral economics a person is no longer unitary, but composed of different selves, the future incarnation that does not keep promises of the current incarnation cannot be held responsible for the consequences of its choice. As a result the person who suffers because of his past actions is in fact a victim of his own past self, who cannot be penalized because does not exist anymore: Dr Jekyll is not the same being as Mr Hyde. In consequence paternalism relies on prevention rather than penalties. But if any action may set off a chain of events that would eventually lead to some harm (theft, murder, assault etc.), it may be prohibited: we may imagine a situation where a shop assistant sells alcohol to an addicted person who later gets intoxicated and commits a crime, but cannot be deemed responsible for his actions due to lack of self-control, so it is the seller who could be punished for the act of sale. Thus a logical consequence of this excessive prevention is the transfer of responsibility from the irrational addict to the rational seller (who should now enforce measures to constrain the behavior of the customer by refusing to sell him alcohol), as well as separation of responsibility and freedom (the seller is obliged to prevent crime and made responsible for it, the customer is relieved of responsibility for his acts and enjoys freedom) (Saint-Paul 2012).

Apart from the above noted fundamental matters that raise philosophical, methodological and ethical concerns, another group of caveats undermines the logic and efficiency of public policy based on behavioral insights.

First of all, policy makers are prone to make irrational decisions as much as ordinary citizens, therefore any paternalism, whether supported by behavioral sciences or not, may be considered by some as a cure not much better than the disease (Glaeser 2006).

As noted above, the choice of the measure of welfare to be maximized, other than based on actual choices, is arbitrary and not objective.

Contrary to libertarian paternalists' claims that their approach does not impose any costs on individuals to whom a particular choice architecture is presented, one may notice that the decision to opt out of the default option involves implicit costs of time and effort.

With no explicit borders of libertarian paternalism there is a risk that implementing this approach is the first stage in a downward slide on a slippery slope towards more outright regulation, imposing bans and limiting freedom.

Finally, people are able to reduce cognitive errors, especially if incentives to do so are strong, which happens more frequently in private markets with price signals rather than in the political sphere realm of public decisions; and in real life outside laboratories (confirmed by demand for information, e.g. consumer reports or self-help books).

\section{CONCLUSIONS}

Human nature is more complex than the neoclassical economic model suggests. In order to explain a wide array of decisions people make, psychological factors must be taken into account. Findings from behavioral economics may be applied not only by decision makers to improve their own choices, but also by 
enterprises, especially their marketing divisions, and public policy makers with the aim of increasing their efficacy.

However, when use of behavioral tools is made, several ethical considerations arise that should be properly addressed. Otherwise we would trigger a movement that could eventually end in suppressing individual freedom in the name of improving people's lives in the way devised by the policy maker.

Further studies on this issue should also aim at eliciting precise mechanisms in which cognitive biases translate into actions and finding optimal methods of their application in real-life situations so as to achieve the desired outcome at the lowest possible cost and in a manner that is least disturbing for liberty.

It must be noted that many of the behavioral tendencies described above contradict each other, for instance changing individuals' behavior requires salient and graphic information, whereas emotions evoked by such information may cause panic that government would prefer to avoid. Therefore much attention must also be paid to mutual interplay of the psychological mechanisms and their effect on behavior.

\section{REFERENCES:}

Acocella N., (2005), The Foundations of Economic Policy: Values and Techniques, Cambridge University Press, Cambridge. Bernheim B.D., Rangel A. (2009), Behavioral Public Economics: Welfare and Policy Analysis with Non-Standard Decision Makers, NBER Working Paper, No. 11518, August.

Camerer C., S. Issacharoff, G. Loewenstein, T. O’Donoghue, M. Rabin (2003), Regulation for Conservatives: Behavioral Economics and the Case for "Asymmetric Paternalism", University of Pennsylvania Law Review, Vol. 151.

Congdon W.J., Kling J.R., Mullainathan S. (2011), Policy and Choice. Public Finance through the Lens of Behavioral Economics, Brooking Institution Press, Washington, D.C.

Dawnay E., H. Shah (2005), Extending the "Rational Man" Model of Human Behaviour: Seven Key Principles, NEF \& Environmental Agency, Bristol.

Dolan P., M. Hallsworth, D. Halpern, D. King, I. Vlaev (2010), Mindspace. Influencing behaviour through public policy, Institute for Government.

Foote C.L., L. Goette, S. Meier (2009), Policymaking Insights from Behavioral Economics. Federal Reserve Bank of Boston, Boston.

Glaeser E.L. (2006), Paternalism And Psychology, Regulation, Summer.

Gnezzy U., Rustichini A. (2000), A Fine Is a Price, Journal of Legal Studies, Vol. XXIX, January.

Gowdy J.M. (2007), Behavioral Economics and Climate Change Policy, Renssealer Working Papers in Economics, No. 0701, January.

Gul F., Pesendorfer W. (2005), The Case for Mindless Economics, in: The Foundations of Positive and Normative Economics, edited by A. Caplin and A. Shotter, Oxford University Press.

Hausman D.M., M.S. McPherson (2008), The Philosophical Foundations of Mainstream Normative Economics, in: The Philosophy of Economics. An Anthology, edited by D.M. Hausman, Cambridge University Press, Cambridge.

Johnson E.J., S.B. Shu, B.G.C. Dellaert, C. Fox, D.G. Goldstein, G. Häubl, R.P. Larrick, J.W. Payne, E. Peters, D. Schkade, B. Wansink, E.U. Weber (2012), Beyond Nudges: Tools of a choice architecture, Marketing Letters, June 2012, Volume 23, Issue 2.

Kahneman D. (2003), Maps of bounded rationality: Psychology for Behavioral Economics, The American Economic Review, 93(5), pp. 1449-1475, December.

Kouchaki M., I.H. Smith (2014), The Morning Morality Effect. The Influence of Time of Day on Unethical Behavior, Psychological Science, January, vol. 25, no. 1. 
Madrian B.C., D.F. Shea (2001), The Power of Suggestion: Inertia in 401(k) Participation and Saving Behavior, Quarterly Journal of Economics, Vol. 116, No. 4.

Mitchell G. (2005), Libertarian Paternalism Is An Oxymoron, Northwestern University Law Review, Vol. 99, No. 3.

O’Donohue T., Rabin M. (2003), Studying Optimal Paternalism, Illustrated by a Model of Sin Taxes, American Economic Review, 93(2).

Saint-Paul G. (2011), The Tyranny of Utility. Behavioral Social Science and the Rise of Paternalism, Princeton University Press, Princeton.

Saint-Paul G. (2012), Liberty and The Post-Utilitarian Society, IZA Discussion Paper, No. 6911, October.

Smith V.L. (2009), Rationality in Economics: Constructivist and Ecological Forms, Cambridge University Press, Cambridge. Sunstein C.R., Thaler R.H. (2008), Nudge. Improving Decisions About Health, Wealth and Happiness, Yale University Press.

Sustainable Development Unit in Defra (2005), Changing Behaviour Through Policy Making, http://archive.defra.gov.uk/ sustainable/government/documents/change-behaviour-model.pdf (May 2014).

Thaler R.H., Sunstein C.R. (2003), Libertarian Paternalism, The American Economic Review, Vol. 93, No. 2, May.

Wright J.D., D.H. Ginsburg (2012), Behavioral Law and Economics: Its Origins, Fatal Flaws, and Implications for Liberty, Northwestern University Law Review, Vol. 106, No. 3. 